\title{
Spatial and temporal disease dynamics of the parasite Hematodinium sp. in shore crabs, Carcinus maenas
}

\author{
Charlotte E. Davies $^{1 *} \mathbb{0}$, Frederico M. Batista ${ }^{1,2}$, Sophie H. Malkin ${ }^{1}$, Jessica E. Thomas ${ }^{1}$, Charlotte C. Bryan ${ }^{1}$, \\ Peter Crocombe ${ }^{1}$, Christopher J. Coates ${ }^{1 *}$ and Andrew F. Rowley ${ }^{1 *}$
}

\begin{abstract}
Background: The parasitic dinoflagellates of the genus Hematodinium represent the causative agent of so-called bitter or pink crab disease in a broad range of shellfish taxa. Outbreaks of Hematodinium-associated disease can devastate local fishing and aquaculture efforts. The goal of our study was to examine the potential role of the common shore (green) crab Carcinus maenas as a reservoir for Hematodinium. Carcinus maenas is native to all shores of the UK and Ireland and the North East Atlantic but has been introduced to, and subsequently invaded waters of, the USA, South Africa and Australia. This species is notable for its capacity to harbour a range of micro- and macro-parasites, and therefore may act as a vector for disease transfer.
\end{abstract}

Methods: Over a 12-month period, we interrogated 1191 crabs across two distinct locations (intertidal pier, semiclosed dock) in Swansea Bay (Wales, UK) for the presence and severity of Hematodinium in the haemolymph, gills, hepatopancreas and surrounding waters (eDNA) using PCR-based methods, haemolymph preparations and histopathology.

Results: Overall, 13.6\% were Hematodinium-positive via PCR and confirmed via tissue examination. Only a small difference was observed between locations with $14.4 \%$ and $12.8 \%$ infected crabs in the Dock and Pier, respectively. Binomial logistic regression models revealed seasonality $(P<0.002)$ and sex $(P<0.001)$ to be significant factors in Hematodinium detection with peak infection recorded in spring (March to May). Male crabs overall were more likely to be infected. Phylogenetic analyses of the partial ITS and 185 rRNA gene regions of Hematodinium amplified from crabs determined the causative agent to be the host generalist Hematodinium sp., which blights several valuable crustaceans in the UK alone, including edible crabs (Cancer pagurus) and langoustines (Nephrops norvegicus).

Conclusions: Shore crabs were infected with the host generalist parasite Hematodinium sp. in each location tested, thereby enabling the parasite to persist in an environment shared with commercially important shellfish.

Keywords: Hematodinium, Endoparasites, Carcinus maenas, Disease connectivity, eDNA, Aquatic vectors, Fisheries, Invasive species

\section{Background}

The dinoflagellate endoparasites of the genus Hematodinium are an important group of disease-causing agents infecting over 40 species of crustaceans worldwide [1].

\footnotetext{
*Correspondence: C.E.Davies@Swansea.ac.uk; C.J.Coates@Swansea.ac.uk; A.F.Rowley@Swansea.ac.uk

${ }^{1}$ Department of Biosciences, College of Science, Swansea University, Swansea SA2 8PP, Wales, UK

Full list of author information is available at the end of the article
}

They were first discovered in the 1930s infecting shore crabs (Carcinus maenas) in northern France but only at low prevalence and the causative agent was named Hematodinium perezi [2]. Species of Hematodinium have been recorded in several commercially important species of crustaceans and considered a major cause of loss of stocks. In Virginia (USA), loss to the blue crab fishery due to infection can exceed USD 500,000 per year in nonepidemic years [1]. Similarly, losses to the Norwegian 
lobster (Nephrops norvegicus) fishery based on the west coast of Scotland (UK) have been estimated to be of the order GBP 2-4 million [3-5]. In another key economic crustacean, the edible crab (Cancer pagurus), infection levels of up to $30 \%$ have been reported in juveniles (prerecruit) in the Bristol Channel (UK), indicating that this infection alone can cause significant reduction in stocks [6]. In France, the fishery for the velvet swimming crab (Necora puber) suffered huge losses from 1984-88 (>96 $\%)$ due to Hematodinium infection [7]. In North America, outbreaks have infected up to a third of the Tanner crab (Chionoecetes bairdi) and snow crab (C. opilio) stocks in southeast Alaska and Newfoundland, respectively $[8,9]$.

Hematodinium spp. have been reported to have seasonal, sex and size related relationships or correlations with their hosts that vary depending on the host species and location $[4,10,11]$. For example, in studies of C. maenas, the prevalence of Hematodinium infection peaked in April, and was significantly higher in males than in females [10]. However, in $N$. norvegicus, peak infection prevalence occurred during the winter [12] and was highest in smaller individuals and females [4]. The timescale of infection by Hematodinium spp. from initial contact through to host death is also highly variable and probably related to host, geographical location and the parasite's genotype [13]. In pre-recruit edible crabs (C. pagurus), infection likely occurs in the latter part of the year between October and December [6]. It can take up to one year for the host to die either due to multiplication of Hematodinium in the haemolymph resulting in metabolic exhaustion $[1,14]$ or due to co-infections [15]. Environmental DNA (eDNA) is increasingly being used to detect the molecular 'signatures' of pathogens in the absence of, or before entry into, a host (i.e. the water column) [16]. Detection of Hematodinium spp. in eDNA samples prior to host contact has led to a previously unreported stage in the parasite life-cycle being suggested $[17,18]$.

The common shore crab (or green crab), C. maenas, is found on all coasts of the UK and Ireland, predominantly in the neritic zone but also at depths greater than $60 \mathrm{~m}$. Although native to the North-East Atlantic from northern Norway southwards to West Africa, it has been introduced to the USA, Sri Lanka, the Red Sea, Madagascar, South Africa and Australia. It is considered to have damaging effects on indigenous species [19, 20]. Shore crabs tolerate a wide range of salinities and temperatures and their establishment in such a diverse range of environments, shared with other important commercial species, makes it an essential subject for disease research. This species is known to harbour a wide range of parasites and pathogens, including Hematodinium spp. [21]. Fisheries for C. maenas occur in Spain, France and Portugal, where hundreds of tons per year of intermoult crabs are exported [22, 23]. Additionally, over one million crabs are removed annually from estuaries in the UK to be sold as bait [24]. In the USA, ovigerous crabs are used as bait for both conch and fish species [25]. The invasive and adaptive nature of this species alongside its extensive use as bait presents a clear rationale for the monitoring of pathogens, which in turn may aid in the management of species of commercial importance $[26,27]$ and help to predict ecosystem functioning [28].

Here, we investigated the presence of Hematodinium spp. in C. maenas across two contrasting locations in South Wales, UK. These locations represent habitats shared with commercially important species of crabs including the edible crab (C. pagurus) and velvet swimming crabs (N. puber). We monitored the presence of this parasite in crab tissues using histology (e.g. gill, hepatopancreas) and PCR (haemolymph). Additionally, we isolated eDNA from the surrounding waters in order to assess fully the spatial and temporal prevalence of patterns of Hematodinium spp.

\section{Methods \\ Study area}

The study took place off the South Wales coast, UK at two distinct locations. The first location, the Prince of Wales Dock, Swansea $\left(51^{\circ} 37^{\prime} 8.76^{\prime \prime} \mathrm{N}, 3^{\circ} 55^{\prime} 36.84^{\prime \prime} \mathrm{W}\right)$, is a mostly disused 27 -acre dock to the east of the River Tawe (Fig. 1). The second location, Mumbles Pier $\left(51^{\circ} 34^{\prime} 8.958^{\prime \prime} \mathrm{N}, 3^{\circ} 58^{\prime} 33.297^{\prime \prime} \mathrm{W}\right)$, is an intertidal rocky shore to the south of Swansea Bay (Fig. 1) facing into the Bristol Channel with a twice daily tide $\sim 8.5 \mathrm{~m}$ in height.

\section{Sample collection}

Once per month, for 12 months from November 2017 to October 2018, the shore crab population was surveyed at both locations. Strings of baited Swedish crayfish traps were deployed and immersed for $24 \mathrm{~h}$, retrieved and 50 crabs were chosen randomly, bagged individually and transported back to the laboratory on ice. In addition, for environmental DNA analysis, three 2-l bottles of seawater from each location were sampled and transported on ice back to the laboratory. In the Dock location, pots were deployed from the pontoon, and water was taken directly from 3 replicate sites (c.60 m apart) across the dock pontoon. In the case of the Pier location, pots were deployed and collected from around the base of the Pier at low tide, and a research vessel was used to collect water from 3 replicate sites adjacent to the Pier $(c .60 \mathrm{~m}$ apart). Water samples were collected from each location for the same 12-month period as the crab sampling, with the exception of December 2017 from the Dock location, which is absent from the data set. 


\section{Laboratory regime}

All crabs were processed on the day of collection. The following biometric data for each crab were taken: carapace width (CW; mm); sex; moult stage [inter-moult (hard) or post-moult (soft)]; fouling (presence of epibionts); pigment loss or shell disease; limb loss; and carapace colour (green, yellow or orange/red). In addition, c. $350 \mu \mathrm{l}$ of haemolymph was withdrawn using a 23-gauge hypodermic needle fitted with a sterile 1-ml syringe and haemolymph appearance was categorised as clear or milky. Haemolymph was fixed 1:1 with $25 \mu \mathrm{l}$ of $5 \%$ formaldehyde $(\mathrm{v} / \mathrm{v})$ in $3 \% \mathrm{NaCl}(\mathrm{w} / \mathrm{v})$ solution and total haemocyte counts were recorded using an improved Neubauer haemocytometer under phase contrast microscopy. A further $25 \mu \mathrm{l}$ of haemolymph was placed onto a microscope slide for primary screening using the phase contrast optics of a BX41 microscope (Olympus, Tokyo, Japan), and $100 \mu \mathrm{l}$ was stored at $-80{ }^{\circ} \mathrm{C}$ for subsequent DNA extraction. If a haemolymph preparation was deemed Hematodinium-positive, the number of parasites/ml haemolymph was calculated as a marker of severity by counting the total number of haemocytes in a haemocytometer and determining the ratio of Hematodinium to haemocytes in haemolymph preparations.

\section{Water filtration}

All water samples were processed in the laboratory on the same day as collection. Two litres of water from 3 replicate sites at each location was first filtered through a sterile $200 \mu \mathrm{m}$ nylon mesh to remove large debris. Next, the water was vacuum filtered through a sterile $0.45 \mu \mathrm{m}$ (pore size), $47 \mathrm{~mm}$ (diameter) polyvinylidene difluoride (PVDF) Durapore ${ }^{\circledR}$ membrane filter (SigmaAldrich, Dorset, UK) $1 \mathrm{l}$ at a time. Six membrane filters per month per location were stored at $-80{ }^{\circ} \mathrm{C}$ for later DNA extraction.

\section{Histopathology}

Tissue histology was used as the secondary tool after PCR, to screen a subset of animals to estimate the severity of, and potential immune responses to, any Hematodinium (e.g. melanisation reactions, haemocyte aggregation). Three gills and three portions $\left(c .0 .5 \mathrm{~cm}^{3}\right)$ of the hepatopancreas/gonad were excised and fixed in Davidson's seawater fixative [29] for $24 \mathrm{~h}$ prior to their storage in $70 \%$ ethanol. Samples were dehydrated in a graded series of ethanol, transferred to Histoclear/Histochoice (Sigma-Aldrich, Dorset, UK) and infiltrated with molten wax using a Shandon ${ }^{\mathrm{TM}}$ automated tissue processor (Thermo Fisher Scientific, Altrincham, UK) prior to embedding. Blocks were cut at 5-7 $\mu \mathrm{m}$ thickness using

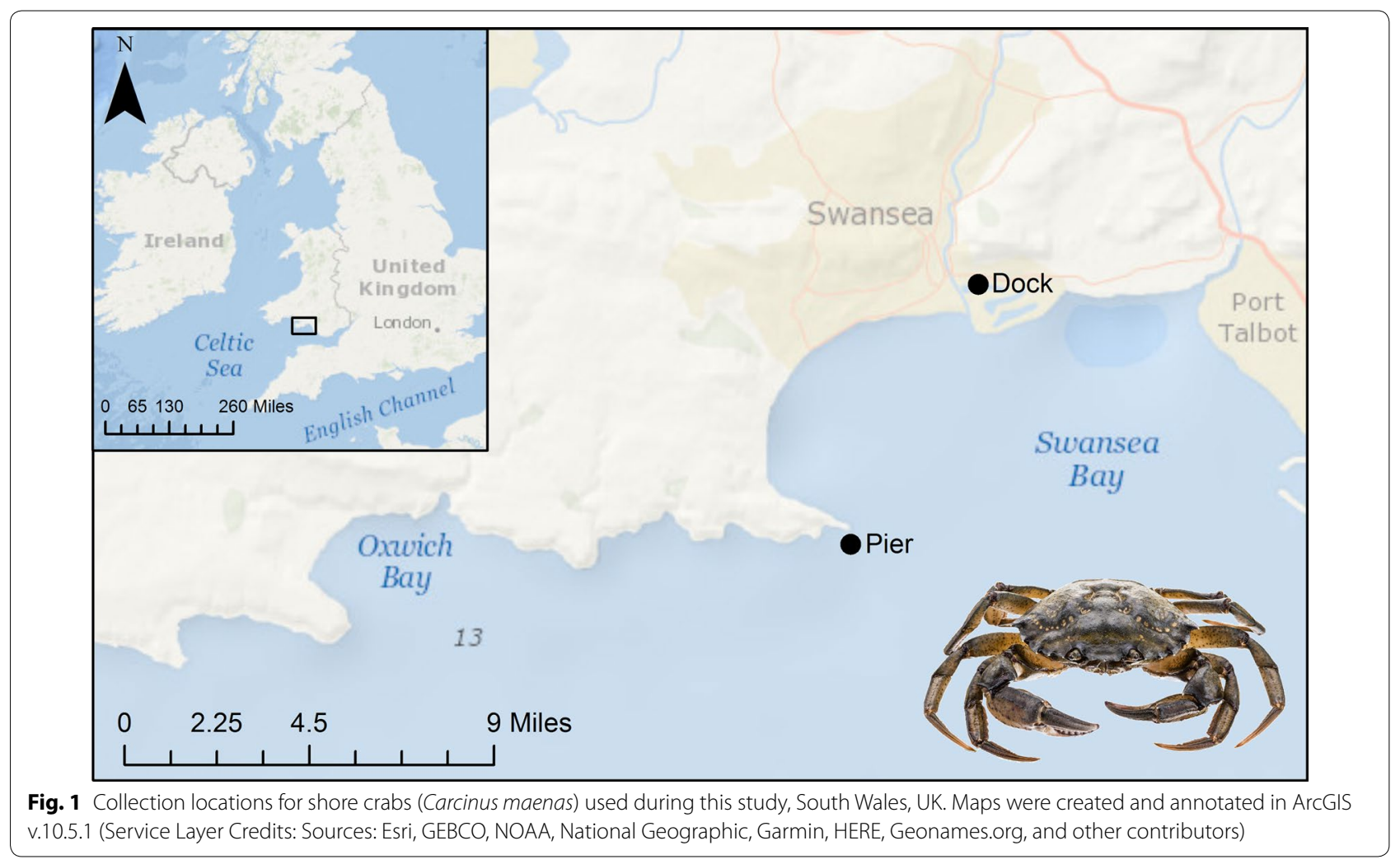


an RM2245 microtome (Leica, Wetzlar, Germany). Sections were mounted on glass slides using albumin-glycerol fixative and stained with Cole's haematoxylin and eosin. Stained slides were viewed and imaged using an Olympus BX41 microscope. Images were adjusted for colour balance and contrast only. Gills and hepatopancreas found to be positive for Hematodinium sp. via PCR were graded $0-4$ for infection severity according to the criteria of Smith et al. [6] (0 signifies subclinical infections, undetected by histology but positive by PCR). The subset screened consisted of all Hematodinium-positive samples using PCR, plus an equal number of control (apparently disease-free) crabs of the same size and sex.

\section{DNA extraction and quantification}

Crab DNA was extracted from $100 \mu \mathrm{l}$ of thawed haemolymph using Qiagen Blood and Tissue Kits (Qiagen, Hilden, Germany) and water eDNA was extracted from each thawed filter membrane using a Qiagen DNeasy PowerWater Kit, both following the manufacturer's instructions. Extracted DNA was quantified using a Qubit $^{\circledR}$ dsDNA High Sensitivity Assay Kit and Qubit ${ }^{\circledR}$ Fluorometer (Invitrogen, California, USA). Following quantification, water eDNA generated from filter membranes of the same replicate site/same month/same location were pooled in equimolar concentrations to give 3 samples per location, per month to be used in downstream analysis.

\section{PCR and sequencing conditions}

All PCR reactions were carried out in $25 \mu \mathrm{l}$ total reaction volumes using $2 \times$ Master Mix (New England Biolabs Inc., Ipswitch, USA), oligonucleotide primers synthesized by Eurofins (Ebersberg, Germany), $1 \mu \mathrm{l}$ of genomic DNA (c.50-200 ng/ $\mu \mathrm{l})$ and performed on a T100 PCR thermal cycler (BioRad Laboratories Inc., Hemel Hempstead, UK). Products derived from PCR were visualized on a $2 \%$ agarose/TBE gel with GreenSafe premium nucleic acid stain (NZYTech, Lisboa, Portugal). For primary diagnostics, general Hematodinium primers targeting a highly variable $18 S$ rRNA gene region (Hemat-F-1487 and Hemat-R-1654, Table 1) were used to verify the presence of any Hematodinium in the extracted DNA. If samples contained a positive signal for Hematodinium in the first instance, a second round of PCR was performed with Hematodinium spp--specific primers with a larger fragment suitable for sequencing (18SF2 and Hem3R, Table 1). Finally, if the second set of primers did not amplify the fragment for sequencing, samples were interrogated further with alternative Hematodinium spp.-specific primers, 18SF2 and ITSR1 (Table 1). Positive samples were re-amplified and purified using HT
ExoSAP-IT ${ }^{\mathrm{TM}}$ Fast high-throughput PCR product cleanup (Thermo Fisher Scientific, Altrincham, UK) in preparation for target sequencing. Amplicons were identified by DNA Sanger sequencing using both forward and reverse primers synthesised by Source BioScience (Nottingham, UK) and Eurofins.

\section{Phylogenetic analyses}

Consensus sequences were constructed from clipped sequences using the CAP contig assembly extension in BioEdit sequence alignment editor [30]. Reference sequences of the respective region from $H$. perezi and Hematodinium sp. recovered from a broad range of crustacean hosts were sourced from GenBank at NCBI [31]: Callinectes sapidus, Chionoecetes angulatus, C. bairdi, C. opilio, C. tanneri, Cancer pagurus, Carcinus maenas, Exopalaemon carinicauda, Hyas coarctatus, $H$. araneus, Liocarcinus depurator, Lithodes couesi, Munida rugosa, Nephrops norvegicus, Pagurus bernhardus, P. prideaux, Penaeus monodon, Portunus trituberculatus and Scylla paramamosain. Sequences from Amoebophyra species (GenBank: HM483395, HQ658161, HM483394 and MK681270) were used as an outgroup for the trees. Multiple sequence alignments were performed in CLUSTAL $\mathrm{X}$ v.2 [32]. Evolutionary analyses and reconstructions were carried out in MEGA X [33] using the maximum likelihood routine based on the Tamura-Nei model. A consensus tree with the highest log likelihood value $(-250.10)$ from 1000 bootstrap re-samplings was annotated using iTOL software [34]. All sequences have been deposited in the GenBank database under the accession numbers MN057783-MN057918 for crab DNA and MN049783-MN049789 for water eDNA (see Additional file 1: Table S4).

\section{Statistical analyses}

Sample size calculations using an alpha value of 0.05 and desired power $>80 \%$ indicated a minimum of 38 (1-sided test) up to 48 (2-sided test) crabs were needed based on an a priori prediction of $15 \%$ Hematodinium prevalence in the C. maenas population (in line with findings of Smith et al. [6] when screening C. pagurus).

Binomial logistic regression models with Logit link functions (following Bernoulli distributions) were used (MASS library) to determine whether specific predictor variables had a significant effect on the probability of finding crabs testing positive for Hematodinium presence in the crab populations sampled. All logistic models were run in RStudio v.1.1.463 using R v.3.5.1. The information theoretic approach was used for model selection and assessment of performance [35]. Initial models are herein referred to as the full models. Once selected, each non-significant predictor variable from the full models 
was sequentially removed using the drop1 function to produce final models with increased predictive power, herein referred to as the reduced models. The drop1 function compares the initial full model with the same model, minus the least significant predictor variable. If the reduced model is significantly different from the initial full model (in the case of binomial response variables, a Chi-square test is used to compare the residual sum of squares of both models), then the removed predictor variable is kept out of the new, reduced model. This process continues hierarchically until a final reduced model is produced [36]. Full models included the input variables: season [winter (Dec '17, Jan '18, Feb '18), spring (Mar '18, Apr '18, May '18), summer (Jun '18, Jul '18, Aug '18), autumn (Sept '18, Oct '18, Nov '17)], CW (continuous number), sex (male or female), colour (green, yellow or orange), pigment loss ( 0 or 1$)$, haemolymph opacity (milky or clear), fouling (presence of epibionts, 0 or 1 ) and limb loss (0 or 1$)$. Location (Pier or Dock) was also used in the first model before sites were separated. Graphics were produced using GraphPad Prism v.8.00 for Windows.

\section{Results}

\section{General population observations}

Overall, 1191 crabs were sampled across the yearlong survey, 603 from the Dock and 588 from the Pier. Of these crabs combined, 9.4\% were Hematodinium-positive using the haemolymph screen alone (Fig. $2 \mathrm{a}-\mathrm{C}$ ), whereas
13.6\% were Hematodinium-positive via PCR, suggesting a larger sub-clinical or carrier presence in the population. The initial screening for the presence of Hematodinium in haemolymph was based on their morphological differences to the host haemocytes. Various forms of Hematodinium were non-adherent (unlike the haemocytes that attach and spread to the slides) and irregular in shape and size with variable refractivity (Fig. 2a-c). Herein, when referring to the presence of Hematodinium, we refer to the occurrence via PCR alone unless otherwise stated.

Model 1 combined the data from both locations, and using the presence of Hematodinium as the response variable, revealed that season, sex and haemolymph opacity were significant factors associated with the presence of the parasite (Table 2, Model 1). Of the male crabs, $17.6 \%$ were Hematodinium-positive whereas just $9.3 \%$ of the females presented the disease, making males nearly twice as likely to become infected (Fig. $3 \mathrm{a}-\mathrm{c}$ ). In terms of haemolymph opacity, $26.7 \%$ of crabs that displayed milky or cloudy white haemolymph were Hematodiniumpositive whereas just $12.6 \%$ of those with clear or 'normal' haemolymph were diseased (Fig. 3d-f). In terms of seasonality, those crabs found in spring (March-May) and summer (June-August) were significantly more likely to be infected by Hematodinium than those found in the autumn/winter (November-January) (17, 15.3, 8.3\%, respectively; Fig. 3g-i). Size (carapace width), crab colour (Fig. 3j-1), pigment loss, fouling (presence of epibionts),

Table 1 Forward and reverse primer sequences used for the amplification of Hematodinium by PCR. Each PCR run included initial denaturation and final extension steps, according to the first and final temperatures, respectively, noted in the thermocycler settings

\begin{tabular}{|c|c|c|c|c|c|c|c|c|}
\hline \multicolumn{4}{|l|}{ Primers } & \multicolumn{3}{|c|}{ Thermocycler settings } & \multirow{2}{*}{$\begin{array}{l}\text { Amplicon } \\
\text { size (bp) }\end{array}$} & \multirow[t]{2}{*}{ References } \\
\hline Direction & Name & Sequence $\left(5^{\prime}-3^{\prime}\right)$ & $\begin{array}{l}\text { Final } \\
\text { concentration } \\
(\mu \mathrm{M})\end{array}$ & $\begin{array}{l}\text { Temperature } \\
\left({ }^{\circ} \mathrm{C}\right)\end{array}$ & Time & No. of cycles & & \\
\hline Forward & Hemat-F-1487 & CCTGGCTCGATAGAGTTG & 0.5 & 94 & $10 \min$ & 30 & 187 & {$[57]$} \\
\hline \multirow[t]{4}{*}{ Reverse } & Hemat-R- 1654 & GGCTGCCGTCCGAATTATTCAC & & 94 & $15 s$ & & & \\
\hline & & & & 54 & $15 s$ & & & \\
\hline & & & & 72 & $30 s$ & & & \\
\hline & & & & 72 & $10 \mathrm{~min}$ & & & \\
\hline Forward & $18 S F 2$ & CAGTTTCTGGAAGTGGCAGCTG & 1 & 94 & $1 \mathrm{~min}$ & 35 & 480 & {$[58,59]$} \\
\hline \multirow[t]{4}{*}{ Reverse } & Hem3R & TAACCCGAGCCGAGGCATTCA & & 94 & $1 \mathrm{~min}$ & & & \\
\hline & & & & 58 & $1 \mathrm{~min}$ & & & \\
\hline & & & & 72 & $1 \mathrm{~min}$ & & & \\
\hline & & & & 72 & $10 \mathrm{~min}$ & & & \\
\hline Forward & 18SF2 & CAGTTTCTGGAAGTGGCAGCTG & 0.5 & 94 & $1 \mathrm{~min}$ & 35 & 380 & [58] \\
\hline \multirow[t]{4}{*}{ Reverse } & ITS R1 & GAAGGGAAGGGGAGAAGAAGC & & 94 & $30 s$ & & & \\
\hline & & & & 57 & $1 \mathrm{~min}$ & & & \\
\hline & & & & 72 & $1 \mathrm{~min}$ & & & \\
\hline & & & & 72 & $7 \mathrm{~min}$ & & & \\
\hline
\end{tabular}


limb loss and location did not have a significant effect (Fig. 4a, d; Additional file 1: Table S1, Model S1).

\section{Presence of Hematodinium in crabs by location}

To further explore the possible relationship between external factors and the presence of Hematodinium, the data were separated and analysed between the two locations (i.e. Dock vs Pier). In the Dock, $14.4 \%$ of crabs surveyed presented Hematodinium. Using the presence of Hematodinium in the Dock as the response variable (Model 2) revealed that sex and haemolymph opacity were significant factors associated with the presence of Hematodinium (Table 2). Of the male crabs in the Dock, 23.3\% presented Hematodinium whereas $6.4 \%$ of females were diseased, making males more than three times as likely to become infected (Fig. 3b). In terms of haemolymph opacity, $26.2 \%$ of crabs that displayed milky or cloudy white haemolymph were Hematodinium-positive whereas $13.5 \%$ of those with clear or 'normal' haemolymph were diseased (Fig. 3e). Season, size (CW), pigment loss, fouling (presence of epibionts), limb loss and location did not have a significant effect (Additional file 1: Table S2, Model S2). The drop1 function deemed crab colour significant enough to be kept in the in the final (reduced) model; however, it had no significant final effect on the presence of Hematodinium in crabs from the Dock (Model 2, Table 2, Fig. 3j).

In the Pier location, $12.8 \%$ of crabs surveyed presented Hematodinium. Using the presence of Hematodinium in the Pier location as the response variable (Model 3), revealed that season, size (CW) and haemolymph opacity were significant factors associated with the presence of Hematodinium (Table 2, Model 3). Those crabs found in the Pier in spring (March-May) were significantly more likely to have Hematodinium than those found in autumn (September-November) and highest overall (18.9 and $7.3 \%$, respectively; Fig. 3i). In terms of size, smaller crabs were significantly more likely to display Hematodinium compared to parasite-free crabs (mean \pm SD: $43.50 \pm 5.14$ vs $46.68 \pm 7.00 \mathrm{~mm}$, respectively; Fig. 4c, f). In terms of haemolymph opacity, $27.3 \%$ of crabs that displayed milky or cloudy haemolymph were Hematodinium-positive, whereas just $11.6 \%$ of those with clear, 'normal' haemolymph were diseased (Fig. 3f). Sex, crab colour, pigment loss, fouling (presence of epibionts), limb loss and location did not have a significant effect (Additional file 1: Table S3, Model S3).

\section{Severity of Hematodinium in infected crabs}

Although the presence of Hematodinium in shore crabs was lowest in the autumn to winter months (September-February), high severity infections (levels L3 and L4) were more prevalent in histological examination of both the gills and the hepatopancreas during these seasons (Fig. 5). Low severity infections (L1) were more prevalent in spring (March-May) and summer (JuneAugust) months (Fig. 5). These data indicate that severity and prevalence of Hematodinium have opposite
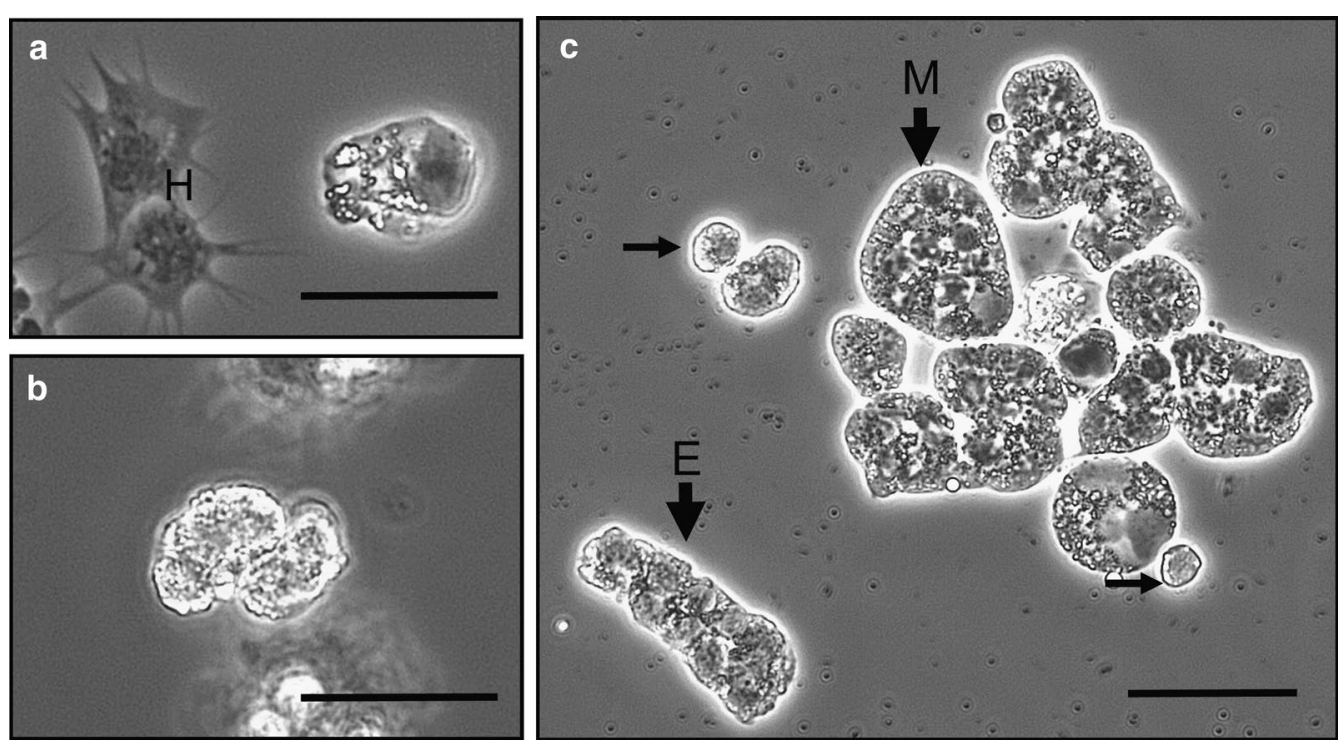

Fig. 2 Identification of Hematodinium in fresh haemolymph preparations using phase contrast microscopy. Parasites were identified by their lack of attachment and spreading to slides ( $c$. the haemocytes, $\mathrm{H}$ ) and their highly refractile nature and irregular sizes and shapes. Parasites were found singly $(\mathbf{a}, \mathbf{b})$ particularly in low severity infections or in clumps $(\mathbf{c})$ in those crabs with high intensity infections. Note the variation in size and shape of the parasites in panel $\mathbf{c}$ with elongate (E), multinucleate (M) and small (unlabelled arrows) forms. Scale-bars: $25 \mu \mathrm{m}$ 
Table 2 Binomial logistic regression models (reduced from the full models, Additional file 1: Table S1) testing the effects of biometric and environmental predictor variables on the overall presence of Hematodinium in the population. Models separated by location: Model 1, total population; Model 2, Dock; Model 3, Pier

\begin{tabular}{|c|c|c|c|c|}
\hline Model & Predictor variable & Estimate (slope) & SE & $P$-value \\
\hline \multicolumn{5}{|l|}{ Model 1} \\
\hline Hemat $\sim$ Season + Sex & Season (spring) & 0.8137 & 0.2628 & $0.00196^{* *}$ \\
\hline + HemoCol & Season (summer) & 0.7437 & 0.2670 & $0.00535^{* *}$ \\
\hline$d f=1188$ & Season (winter) & 0.4678 & 0.2740 & 0.08776 \\
\hline \multirow[t]{2}{*}{ AIC: 914.72} & Sex (male) & 0.7940 & 0.1828 & $1.4 \mathrm{e}-05^{* * *}$ \\
\hline & HemoCol (milky) & 1.1187 & 0.2716 & $3.8 \mathrm{e}-05^{* * *}$ \\
\hline \multicolumn{5}{|l|}{ Model 2} \\
\hline HematDock Sex & Sex (male) & 1.4790 & 0.2918 & $7.4 \mathrm{e}-07^{* * *}$ \\
\hline + Colour + HemoCol & Colour (orange) & -0.5830 & 0.3827 & 0.1277 \\
\hline$d f=595$ & Colour (yellow) & 0.3667 & 0.2808 & 0.1915 \\
\hline AIC: 450.92 & HemoCol (milky) & 1.1323 & 0.4070 & $0.0054^{* *}$ \\
\hline \multicolumn{5}{|l|}{ Model 3} \\
\hline HematPier Season & Season (spring) & 0.99428 & 0.38751 & $0.010293^{*}$ \\
\hline$+\mathrm{CW}+\mathrm{HemoCol}$ & Season (summer) & 0.75876 & 0.40444 & 0.060645 \\
\hline$d f=586$ & Season (winter) & 0.35552 & 0.42248 & 0.400067 \\
\hline \multirow[t]{2}{*}{ AIC: 430.7} & $\mathrm{CW}$ & -0.06889 & 0.02065 & $0.000848^{* * *}$ \\
\hline & HemoCol (milky) & 1.17749 & 0.38636 & $0.002306^{* *}$ \\
\hline
\end{tabular}

*Statistically significant ${ }^{*} P \leq 0.05,{ }^{* *} P \leq 0.01,{ }^{* * *} P \leq 0.001$

Abbreviation: $\mathrm{SE}$, standard error

seasonal patterns with high severity and low prevalence in autumn-winter and low severity and higher prevalence in spring-summer.

Histological examination revealed changes in the morphology of these parasites depending on the severity of infection. For example, in low severity infections (L1) the Hematodinium were often elongate and multinucleate forms attached to host tissues such as the gills (Fig. 6a), together with rounded forms apparently free in circulation. In high severity infections (L3-4), gill lamellae were filled with Hematodinium (Fig. 6b) and intertubular spaces in the hepatopancreas were swollen and replete with these parasites (Fig. 6c). The Hematodinium in these spaces in both gills and hepatopancreas were a mix of rounded, elongate and multinucleate forms (Fig. 6d, e) similar to those seen in the haemolymph preparations examined using phase contrast microscopy (Fig. 2a-c). There was no evidence of any direct host response to the presence of Hematodinium in the tissues such as encapsulation/nodule formation [37]. Where encapsulation of damaged or necrotic host tissues did occur, i.e. in the tubules of the hepatopancreas, these events were independent of the presence of these parasites and the various forms of Hematodinium were not seen within the haemocyte sheaths surrounding damaged tissues (not shown). In Hematodinium-infected crabs, there was no evidence that tissue damage was caused by the presence of Hematodinium alone. No gross differences in the histopathology of Hematodinium infections were seen between crabs collected from either the Docks or the Pier.

\section{Presence of Hematodinium in water samples}

Of the 69 water samples (36 for Pier, 33 for Dock) screened using the primary Hemat-F-1487/HematR-1654 oligonucleotides, no water sample from the Dock location was positive. In the Pier location, the water samples from the months of November and December, across all 3 replicates, plus 1 replicate from August were positive for Hematodinium. From these positive samples, none amplified successfully using the subsequent 18SF2/ Hem3R or 18SF2/ITSR1 oligonucleotides and so were sequenced using the primary Hemat-F-1487/HematR-1654 oligonucleotides and deposited in the GenBank database under the accession numbers MN049783MN049789 (Additional file 1: Table S4).

\section{Phylogenetic analyses}

Of the 162 Hematodinium-positive crab samples using the Hemat-F-1487/Hemat-R-1654 oligonucleotides, 149 were re-amplified successfully for sequencing using the 18SF2/Hem3R and 12 with the 18SF2/ITSR1 oligonucleotides. One sample (Pier 40 April) did not amplify successfully using the 18SF2/Hem3R or 18SF2/ ITSR1 oligonucleotides and was instead sequenced with the Hemat-F-1487/Hemat-R-1654 oligonucleotides. 


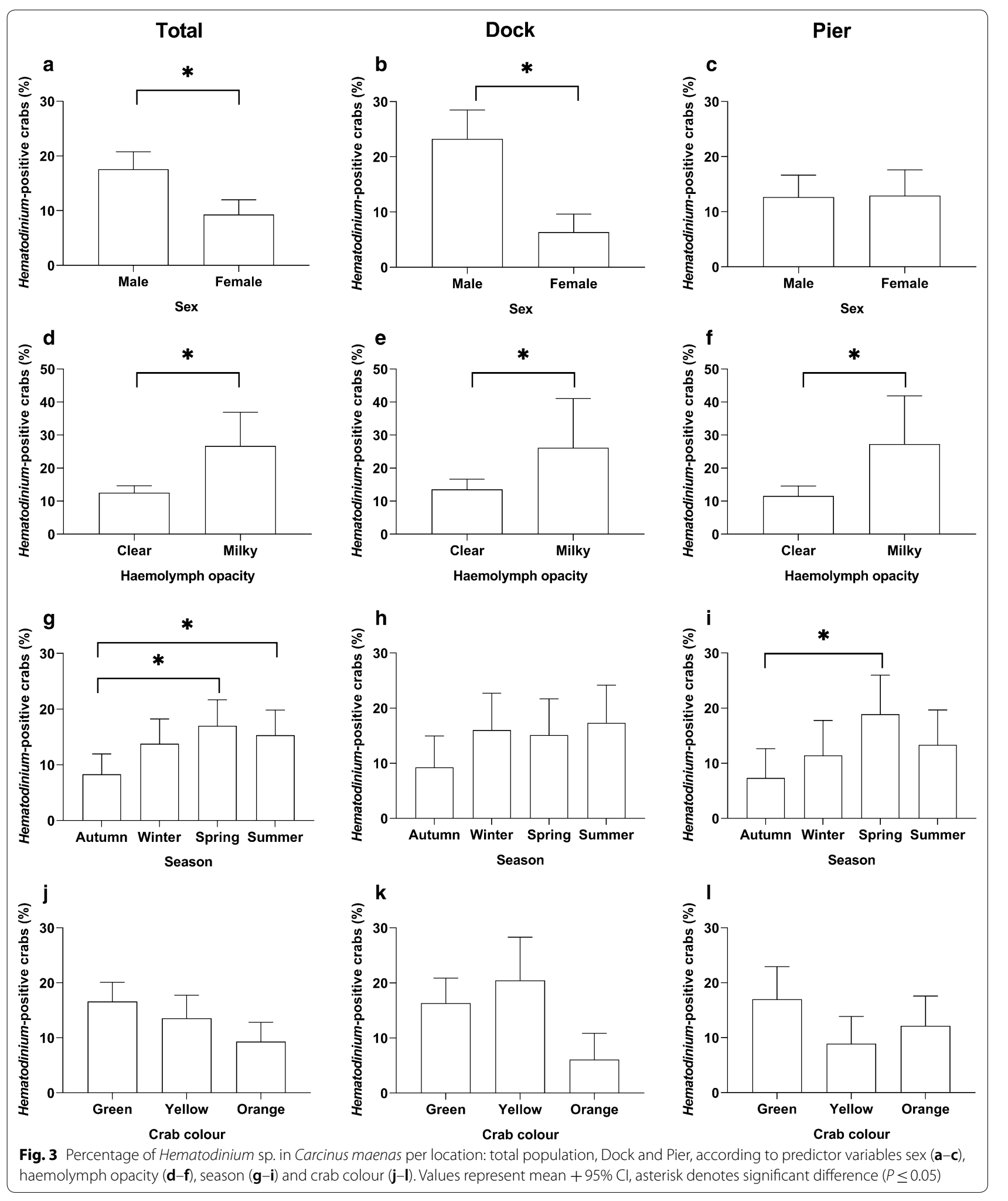

Following quality control, 136 of these sequences (of the ITS1 and partial $18 S$ rRNA gene regions of Hematodinium) were combined with 126 reference sequences for evolutionary analyses (Fig. 7) and deposited in the GenBank database under the accession numbers MN057783-MN057918 (Additional file 1: Table S4). A 

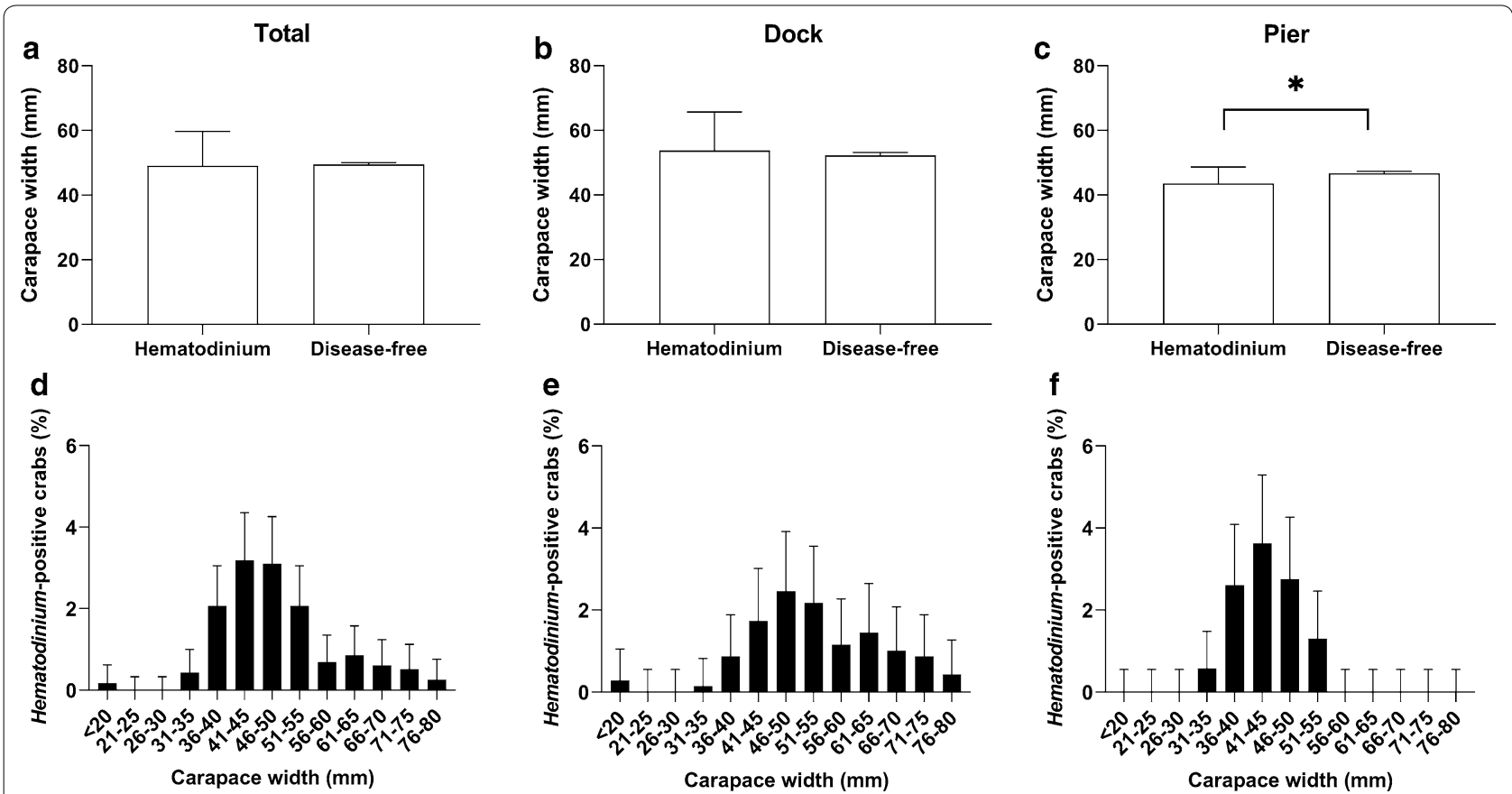

Fig. 4 Carapace width ( $\mathrm{mm}$ ) of C. maenas presenting Hematodinium and those'Hematodinium-free' per location: total population (a), Dock (b) and Pier (c). Also shown, size distribution in $5 \mathrm{~mm}$ size groups of C. maenas presenting Hematodinium per location: total population (d), Dock (e) and Pier (f). Values represent mean $+95 \% \mathrm{Cl}$, asterisk denotes significant difference $(P \leq 0.05)$

single sequence, namely Pier 24 October, shared considerable similarity (490 bp, 100\% coverage, $98.2 \%$ identity) to a $H$. perezi clone from the harbour crab $L$. depurator (GenBank: EF065708) by Small et al. [38]. The remaining 135 sequences shared high similarity (>95\% coverage and identity) with the so-called Hematodinium sp. clones retrieved from a plethora of hosts, including shore crabs (Carcinus maenas), edible crabs (Cancer pagurus), tanner crabs (Chionoecetes spp.) and langoustines $(N$. norvegicus). The topology of the consensus phylogram revealed two distinct, highly supported, clades of Hematodinium A and B (Fig. 7). Clade A consists entirely of $H$. perezi and forms three clusters with respect to established genotypes (I, L. depurator; II, South-East Asia; III, C. sapidus), which is in good agreement with several previous assessments [38-41]. Sequences from Hematodinium-positive crabs across both locations (Pier and Dock) and every month of the year-long survey are distributed within Clade B, thereby suggesting that the parasite most likely infecting C. maenas in our two locations is the generalist Hematodinium sp.

\section{Discussion}

The parasitic dinoflagellate Hematodinium is present in common shore crabs across at least two locations in Swansea Bay, UK (the Prince of Wales Dock and Mumbles Pier), with both the general Hematodinium sp. and
H. perezi detected. Both locations sampled showed a seasonal trend of Hematodinium presence, with high prevalence but low severity (i.e. low parasite load) of infection in the haemolymph and gill/hepatopancreas histopathology in spring to summer. In the autumn months, the number of crabs found to harbour Hematodinium was significantly lower but these individuals had higher severity infections. This gross Hematodinium burden in autumn/winter crabs is accompanied by clear signals of Hematodinium eDNA in the surrounding waters (in November and December), indicating that infectious morphs of the parasite are liberated to target other hosts at this time. Aside from seasonality, haemolymph opacity, sex and size were also associated with the presence of the parasite. In terms of phylogeny, the vast majority of the Hematodinium sp. found in this study (>99\%) reside in Clade B, alongside other generalist Hematodinium sequences.

The role of seasonality in relation to Hematodinium presence has been noted in studies of many host species $[6,10,12,42-50]$. Seasonal prevalence of the parasite also seems to be host specific, mostly related to location, and therefore temperature and salinity. We found that Hematodinium prevalence is high with a low infection intensity in the spring/summer months. Chualáin et al. [42] noted that infection intensity rather than prevalence played an important role in the presence of Hematodinium. In 

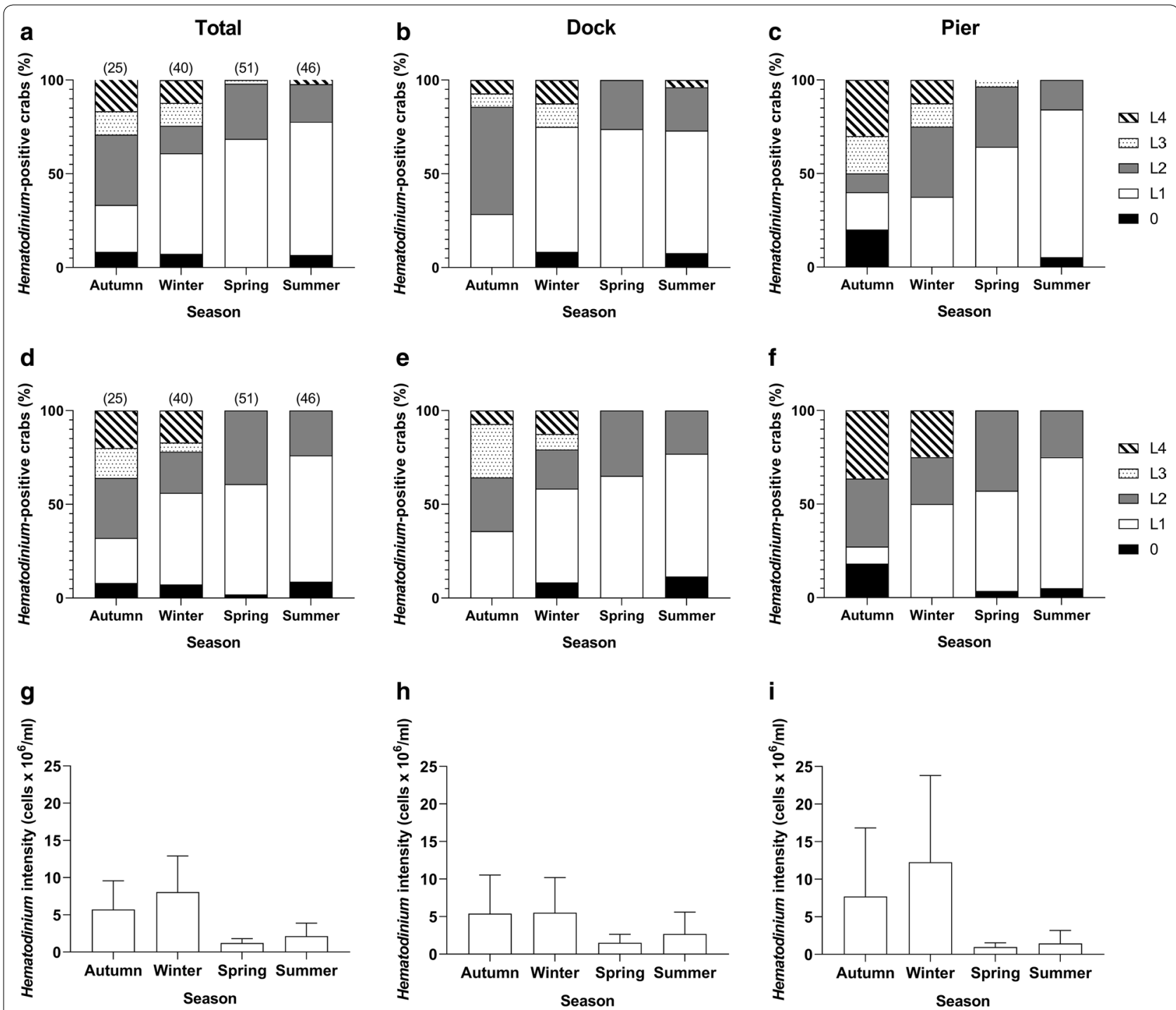

Fig. 5 Temporal changes in the severity of Hematodinium infection of C. maenas in gill (a-c) and hepatopancreas (d-f) histopathology. Hematodinium presence was first determined via $\mathrm{PCR}$, and for all positives, severity of infection was determined using histological analysis ( $L 1$ being the lowest, L4 being the highest; see Smith et al. [6] for grading criteria; zero signifies subclinical infections, undetected by histology but positive by PCR). Values in parentheses are the total number of positive crabs identified by PCR in each sample. $\mathbf{g}-\mathbf{i}$ Parasites/ml haemolymph as a marker of severity, using crabs Hematodinium-positive via haemolymph preparations only (i.e. clinical infections)

that study, it was found that intensity of Hematodinium infection was significantly higher, with peaks occurring in late autumn/early winter months. Smith et al. [6] recorded similar patterns in C. pagurus in two locations in South Wales (including Mumbles Pier, as in the present study) with high numbers of animals infected in the spring to summer but with low severity. Instead, in November, fewer crabs were infected but these animals had hefty parasite loads in their haemolymph and other tissues. These results suggest that seawater temperature or an environment-linked process could be a key factor in triggering the final stages of infection. The apparent presence of Hematodinium in all seawater eDNA samples in November and December in the present study is further evidence for this hypothesis. After peak Hematodinium prevalence in spring/summer, development of the parasite within host haemolymph and tissue could lead to high severity in a small number of surviving crabs by autumn and winter. The presence of Hematodinium in seawater eDNA samples is probably from moribund individuals releasing infective stage dinospores into the water, in turn causing the low severity infections seen the following spring (described above). Hematodinium sp. have also been found in environmental samples (seawater and sediment) in Maryland and Virginia coastal bay ecosystems in the USA, whereby the 'free-living' 


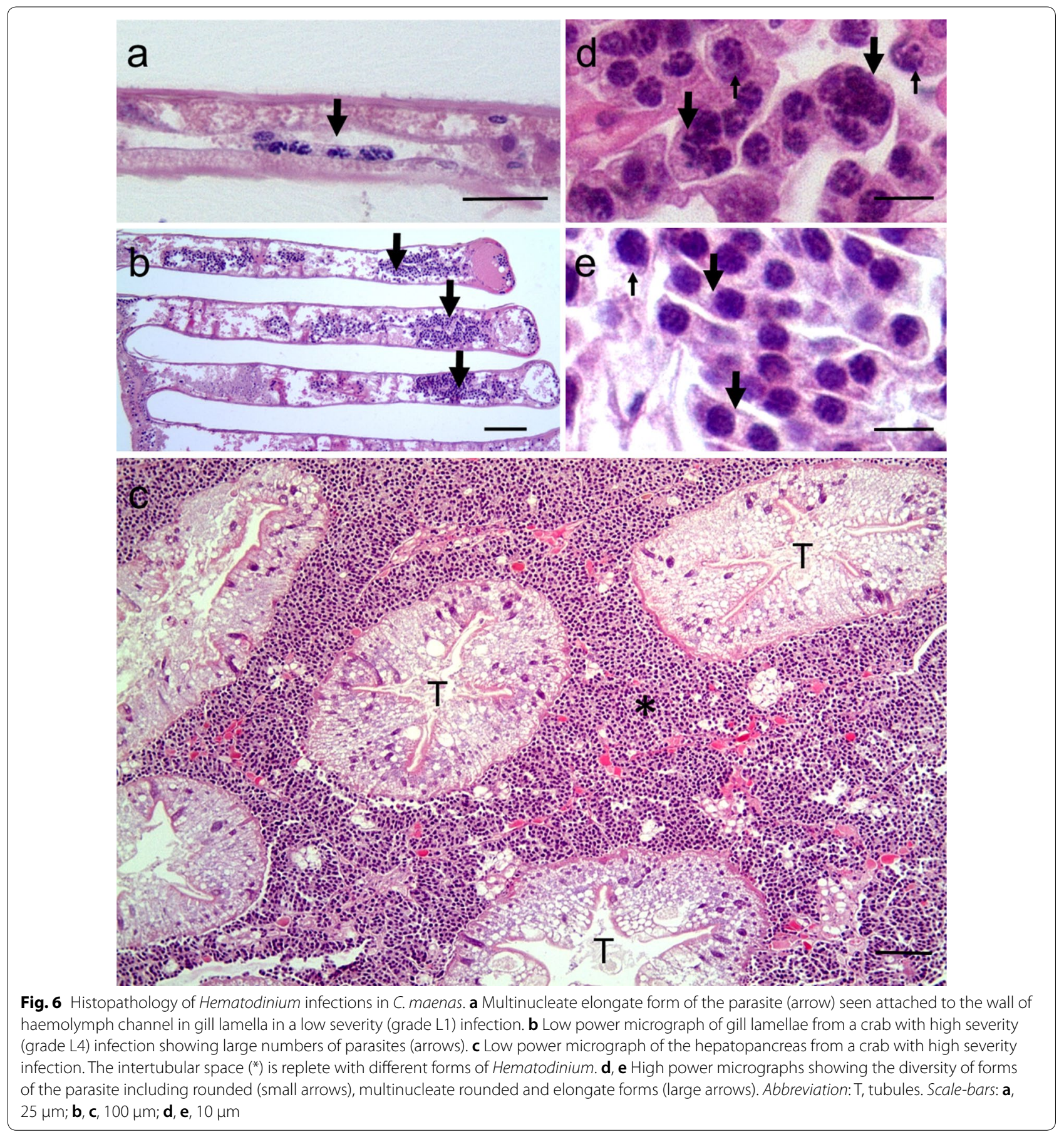

Hematodinium sp. occurred in the ecosystem earlier than peak infection presence in the crabs, a similar observation to ours [18].

In the present study, sex played a role in the presence of Hematodinium in the Dock location only. These results are in line with previous work, whereby male $C$. maenas in the Clyde Sea, Scotland were found with higher levels of Hematodinium via PCR (e.g. [10]). Additionally, male
C. pagurus in the north and southeast of Ireland were found with higher levels of Hematodinium [42]. Whilst smaller crabs were significantly more likely to display Hematodinium in the Pier location only, this phenomenon has also been observed in $N$. norvegicus, whereby infection prevalence was highest in smaller individuals [4]. This pattern is common in many species. For example, medium size and juvenile C. sapidus ( $\leq 30 \mathrm{~mm} \mathrm{CW}$ ) 


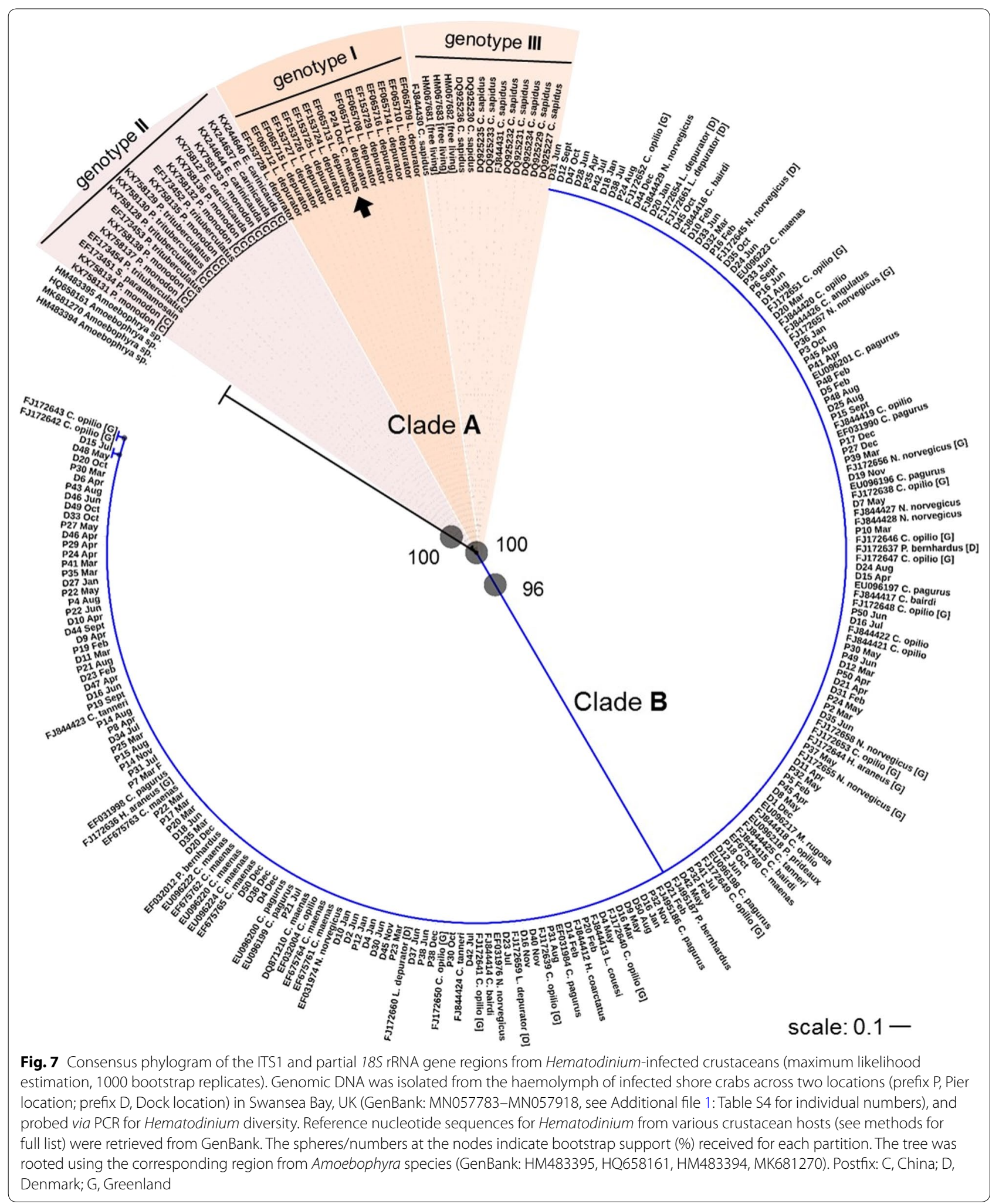


have the highest infection prevalence [51]. It has been suggested that since smaller crustaceans moult more frequently, there will be a greater parasite prevalence as moulting can leave the crustacean vulnerable to pathogen entry $[4,10,52]$. It must be noted that although overall and in the Pier location higher numbers of most recentlymoulted (green) crabs were Hematodinium-positive, this difference was not deemed significant in the final models. The absence of a size-related pattern in the Dock location could be because it is a semi-closed location and is unaffected by tidal height unlike the Pier location. Dock crabs may be more settled and less likely to move as in the 'open' Pier location.

Phylogenetic reconstructions demonstrated clearly that there was little difference in the ecotype diversity of Hematodinium sequences between location (Pier and Dock) or month. Most sequences were distributed within Clade B, with a single sequence in the $H$. perezi-dominated Clade $\mathrm{A}$. This suggests that the parasite infecting $C$. maenas across both locations is most likely the generalist Hematodinium sp. The taxonomic diversity of Hematodinium spp. has been discussed at length in the literature. Small [53] reviewed the global diversity and distribution of these parasites and most notably, Hamilton et al. [54] compared the genotypic variability of Hematodinium from North Atlantic hosts and presented three clades, corresponding to host species, rather than to geographical location. Jensen et al. [39] presented evidence of two clades of Hematodinium in the northern hemisphere: one clade (A) isolated from $C$. sapidus and $L$. depurator and the other clade (B) found in all other host species from both the North Atlantic and Pacific Oceans. Clade A was affiliated with the type-species $H$. perezi identified by Small et al. [38] and three distinct genotypes (I, II, III): Genotype I in the English Channel; Genotype II off the east coast of China; and Genotype III along the east coast of the USA $[38,40]$. These genotypes have also been referred to as 'Clades' [41]. By combining our sequence data with 126 references from GenBank, we provide strong evidence in agreement with previous studies that there are two broad groups of disease-causing Hematodinium: namely (i) H. perezi, which can be separated by distinct host species and geographical locations; and (ii) Hematodinium sp., which is pervasive.

The edible (brown) crab is worth around GBP 50 million per year to the UK and Ireland, and lives alongside shore crabs when in the intertidal zone [55]. Previous reports of Hematodinium presence in pre-recruit edible crabs in the Bristol Channel indicate up to $30 \%$ of individuals are infected [6]. Our data demonstrate clearly that shore crabs in this commercially important region can facilitate Hematodinium persistence. As discussed, severity and temporal profiles are rather similar between the edible and shore crabs and the hypothesis that $C$. maenas may act as a vector for diseases in the commercially important $C$. pagurus remains a key finding of this study. Additionally, Hamilton et al. [10] found Hematodinium in seven crustacean species with prevalence reaching almost $60 \%$ in hermit crabs (P. bernhardus) and 30\% in C. pagurus and N. puber, with prevalence in Munida rugosa and Pagurus bernhardus, peaking in April (much like C. maenas in the present study). This is pertinent as transfer of Hematodinium between species most likely occurs via predation of infected animals, and hermit crabs are common in the diet of larger predatory crabs. Lohan et al. [56] also examined c.1800 crustaceans along the Delmarva Peninsula (Virginia, USA) over a two-year period and found Hematodinium in five hosts additional to the American blue crab, C. sapidus. Sequencing of the ITS1 region demonstrated clearly that the same Hematodinium found in the commercially sensitive blue crabs is present in taxonomically diverse hosts, including an amphipod (Caprella geometrica).

\section{Conclusions}

The seasonal trend of Hematodinium sp. presence in host crabs, as well eDNA signals, confirm a whole parasite life-cycle in Swansea Bay, enabling us to 'track' it in the water column and into the host. The association of Hematodinium sp. presence with both crab sex and size indicates a relationship with moulting, also noted by other studies. Encountering Hematodinium at relatively high percentages across two small populations gives an insight into reservoirs of crustacean diseases in the aquatic environment, with implications for commercially important species sharing the same habitat.

\section{Supplementary information}

Supplementary information accompanies this paper at https://doi. org/10.1186/s13071-019-3727-x.

Additional file 1: Table S1. Full model used in order to predict response variable of presence of Hematodinium sp. before reduction. Asterisk denotes significance $(P \leq 0.05)$. Table $\mathbf{S 2}$. Full model used in order to predict response variable of presence of Hematodinium sp. in the Dock location before reduction. Asterisk denotes significance $(P \leq 0.05)$. Table S3. Full model used in order to predict response variable of presence of Hematodinium sp. in the Pier location before reduction. Asterisk denotes significance $(P \leq 0.05)$. Table S4. Accession numbers, deposited in GenBank, and corresponding sampling numbers for all Hematodiniumpositive animals successfully sequenced from study, and used in the phylogenetic tree (Fig. 7).

\section{Abbreviations}

CW: carapace width; NCBI: National Center for Biotechnology Information; PCR: polymerase chain reaction; rRNA: ribosomal ribonucleic acid; TBE: trisborate-ethylenediaminetetraacetic acid. 


\section{Acknowledgements}

The authors should like to thank Ms. Jenna Haslam and Ms. Emma Quinn, and boat skippers, Mr. Keith Naylor, Mr. Max Robinson and Mr. Barry Thomas, for assistance in the laboratory and field, respectively.

\section{Authors' contributions}

CJC and AFR conceived the study. CED, FB, SHM, CJC and AFR designed the experimental and fieldwork plan. All authors contributed to experimental work. All authors read and approved the final manuscript.

\section{Funding}

This study was part-funded by the European Regional Development fund through the Ireland Wales Cooperation Programme, BLUEFISH, awarded to AFR and CJC. AFR was also part-funded by the BBSRC/NERC ARCH UK Aquaculture Initiative (BB/P017215/1), and start-up funds from Swansea University assigned to CJC were used to supplement this study.

\section{Availability of data and materials}

All data generated or analysed during this study are included in this published article and its additional files. All newly generated DNA sequences have been submitted to the GenBank database under the accession numbers MN057783-MN057918 for crab DNA and MN049783-MN049789 for water eDNA.

\section{Ethics approval and consent to participate}

Not applicable.

\section{Consent for publication}

Not applicable.

\section{Competing interests}

The authors declare that they have no competing interests.

\section{Author details}

${ }^{1}$ Department of Biosciences, College of Science, Swansea University, Swansea SA2 8PP, Wales, UK. ${ }^{2}$ Present Address: Centre for Environment Fisheries and Aquaculture Science (CEFAS), Weymouth, Dorset, UK.

Received: 11 July 2019 Accepted: 23 September 2019

Published online: 11 October 2019

\section{References}

1. Stentiford GD, Shields JD. A review of the parasitic dinoflagellates Hematodinium species and Hematodinium-like infections in marine crustaceans. Dis Aquat Org. 2005;66:47-70.

2. Chatton E, Poisson R. Sur l'existence, dans le sang des Crabes, de Péridiniens parasites: Hematodinium perezi n. g., n. sp. (Syndinidae). CR Séances Soc Biol Paris. 1931;105:553-7.

3. Field RH, Chapman CJ, Taylor AC, Neil DM, Vickerman K. Infection of the Norway lobster Nephrops norvegicus by a Hematodinium-like species of dinoflagellate on the west coast of Scotland. Dis Aquat Org. 1992;13:1-15.

4. Stentiford G, Neil DM, Atkinson RJA. The relationship of Hematodinium infection prevalence in a Scottish Nephrops norvegicus population to season, moulting and sex. ICES J Mar Sci. 2001;58:814-23.

5. Albalat A, Collard A, Brucem C, Coates CJ, Fox CJ. Physiological condition, short-term survival, and predator avoidance behavior of discarded Norway lobsters (Nephrops norvegicus). J Shellfish Res. 2016;35:1053-65.

6. Smith AL, Hirschle L, Vogan CL, Rowley AF. Parasitization of juvenile edible crabs (Cancer pagurus) by the dinoflagellate, Hematodinium sp.: pathobiology, seasonality and its potential effects on commercial fisheries. Parasitology. 2015;142:428-38.

7. Wilhelm G, Mialhe E. Dinoflagellate infection associated with the decline of Necora puber crab populations in France. Dis Aquat Org. 1996;26:213-9.

8. Meyers TR, Morado JF, Sparks AK, Bishop GH, Pearson T, Urban D, et al. Distribution of bitter crab syndrome in Tanner crabs (Chionoecetes bairdi, C. opilio) from the Gulf of Alaska and the Bering Sea. Dis Aquat Org. 1996;26:221-7.

9. Shields JD, Taylor DM, Sutton SG, O'Keefe PG, Ings DW, Pardy AL. Epidemiology of bitter crab disease (Hematodinium sp.) in snow crabs Chionoecetes opilio from Newfoundland, Canada. Dis Aquat Org 2005;64:253-64.

10. Hamilton KM, Shaw PW, Morritt D. Prevalence and seasonality of Hematodinium (Alveolata: Syndinea) in a Scottish crustacean community. ICES J Mar Sci. 2009;66:1837-45.

11. Stentiford GD, Green M, Bateman K, Small HJ, Neil DM, Feist SW. Infection by a Hematodinium-like parasitic dinoflagellate causes pink crab disease (PCD) in the edible crab Cancer pagurus. J Invertebr Pathol. 2002;79:179-91.

12. Briggs RP, McAliskey M. The prevalence of Hematodinium in Nephrops norvegicus from the western Irish Sea. J Mar Biol Assoc UK. 2002;82:427-33.

13. Smith AL, Rowley AF. Effects of experimental infection of juvenile edible crabs Cancer pagurus with the parasitic dinoflagellate Hematodinium sp. J Shellfish Res. 2015;34:511-9.

14. Shields JD, Scanlon C, Volety A. Aspects of the pathophysiology of blue crabs, Callinectes sapidus, infected with the parasitic dinoflagellate Hematodinium perezi. Bull Mar Sci. 2003;72:519-35

15. Mullen TE, Nevis KR, O'Kelly CJ, Gast RJ, Frasca S. Nuclear small-subunit ribosomal RNA gene-based characterization, molecular phylogeny and PCR detection of the Neoparamoeba from western Long Island Sound lobster. J Shellfish Res. 2005;24:719-31.

16. Bass D, Stentiford GD, Littlewood DTJ, Hartikainen H. Diverse applications of environmental DNA methods in parasitology. Trends Parasitol. 2015:31:499-513.

17. Hanif AW, Dyson WD, Bowers HA, Pitula JS, Messick GA, Jagus R, et al. Variation in spatial and temporal incidence of the crustacean pathogen Hematodinium perezi in environmental samples from Atlantic coastal bays. Aquat Biosyst. 2013;9:11

18. Pitula JS, Dyson WD, Bakht HB, Njoku I, Chen F. Temporal distribution of genetically homogenous "free-living" Hematodinium sp in a Delmarva coastal ecosystem. Aquat Biosyst. 2012:8:16.

19. Tanner JE. The influence of introduced European green crabs (Carcinus maenas) on habitat selection by juvenile native blue crabs (Portunus pelagicus). Estuar Coast. 2007;30:601-6.

20. Leignel V, Stillman JH, Baringou S, Thabet R, Metais I. Overview on the European green crab Carcinus spp. (Portunidae, Decapoda), one of the most famous marine invaders and ecotoxicological models. Environ Sci Pollut Res. 2014:21:9129-44.

21. Bojko J, Stebbing PD, Dunn AM, Bateman KS, Clark F, Kerr RC, et al. Green crab Carcinus maenas symbiont profiles along a North Atlantic invasion route. Dis Aquat Org. 2018;128:147-68.

22. Pascoal S, Creer S, Taylor MI, Queiroga H, Carvalho G, Mendo S. Development and application of microsatellites in Carcinus maenas: genetic differentiation between northern and central Portuguese populations. PLOS ONE. 2009;4:e7268.

23. Klassen $\mathrm{G}$, Locke A. A biological synopsis of the European green crab, Carcinus maenas: Canadian manuscript report of fisheries and aquatic sciences 2818. Moncton: Fisheries and Oceans Canada; 2007.

24. Sheehan EV, Thompson RC, Coleman RA, Attrill MJ. Positive feedback fishery: population consequences of 'crab-tiling' on the green crab Carcinus maenas. J Sea Res. 2008:60:303-9.

25. Fulton BA. The spatial and temporal distribution, population growth strategies and options for the removal of the invasive shore crab Carcinus maenas in two New Hampshire estuaries. MSc. Thesis, University of New Hampshire, USA; 2011. https://pdfs.semanticscholar.org/0184/ab91a d097a81e34300ba8851ef26fd88d8d5.pdf.

26. Wootton EC, Woolmer AP, Vogan CL, Pope EC, Hamilton KM, Rowley AF. Increased disease calls for a cost-benefits review of marine reserves. PLoS ONE. 2012;7:e51615.

27. Davies CE, Johnson AF, Wootton EC, Greenwood SJ, Clark KF, Vogan CL, et al. Effects of population density and body size on disease ecology of the European lobster in a temperate marine conservation zone. ICES J Mar Sci. 2015;72:1128-38.

28. Wood CL, Micheli F, Fernández M, Gelcich S, Castilla JC, Carvajal J. Marine protected areas facilitate parasite populations among four fished host species of central Chile. J Anim Ecol. 2013:82:1276-87.

29. Hopwood D. Fixation and fixatives. In: Bamcroft J, Stevens A, editors. Theory and practice of histopathological techniques. Hong Kong: Churchill Livingstone; 1996. p. 23-46. 
30. Hall T. BioEdit : a user-friendly biological sequence alignment editor and analysis program for Windows 95/98/NT. Nucleic Acids Symp Ser. 1999;41:95-8.

31. Benson DA, Cavanaugh M, Clark K, Karsch-Mizrachi I, Lipman DJ, Ostell J, et al. GenBank. Nucleic Acids Res. 2017;45:D37-42.

32. Larkin MA, Blackshields G, Brown NP, Chenna R, Mcgettigan PA, McWilliam H, et al. Clustal W and Clustal X version 2.0. Bioinformatics. 2007;23:2947-8.

33. Kumar S, Stecher G, Li M, Knyaz C, Tamura K. MEGA X: molecular evolutionary genetics analysis across computing platforms. Mol Biol Evol. 2018;35:1547-9.

34. Letunic I, Bork P. Interactive Tree Of Life (iTOL) v4: recent updates and new developments. Nucleic Acids Res. 2019;1:W256-9.

35. Richards SA. Testing ecological theory using the information-theoretic approach: examples and cautionary results. Ecology. 2005;86:2805-14

36. Zuur AF, leno EN, Walker NJ, Saveliev AA, Smith GM. GLM and GAM for absence-presence and proportional data. In: Zurr AF, editor. Mixed effects models and extensions in ecology with R., Statistics for Biology and HealthNew York: Springer; 2009.

37. Rowley AF, Smith AL, Davies CE. How does the dinoflagellate parasite Hematodinium outsmart the immune system of its crustacean hosts? PLoS Pathog. 2015;11:e1004724.

38. Small HJ, Shields JD, Reece KS, Bateman K, Stentiford GD. Morphological and molecular characterization of Hematodinium perezi (Dinophyceae: Syndiniales), a dinoflagellate parasite of the harbour crab, Liocarcinus depurator. J Eukaryot Microbiol. 2012;59:54-66.

39. Jensen P, Califf K, Lowe V, Hauser L, Morado J. Molecular detection of Hematodinium sp. in Northeast Pacific Chionoecetes spp. and evidence of two species in the Northern Hemisphere. Dis Aquat Org. 2010;89:155-66.

40. Xiao J, Miao X, Li C, Xu W, Zhang X, Wang Z. Genetic variations of the parasitic dinoflagellate Hematodinium infecting cultured marine crustaceans in China. Protist. 2016;167:597-609.

41. Wang JF, Li M, Xiao J, Xu WJ, Li CW. Hematodinium spp. infections in wild and cultured populations of marine crustaceans along the coast of China. Dis Aquat Org. 2017;124:181-91.

42. Chualáin CN, Hayes M, Allen B, Robinson M. Hematodinium sp. in Irish Cancer pagurus fisheries: infection intensity as a potential fisheries management tool. Dis Aquat Org. 2009;83:59-66.

43. Field RH, Hills JM, Atkinson RJA, Magill S, Shanks AM. Distribution and seasonal prevalence of Hematodinium sp. infection of the Norway lobster (Nephrops norvegicus) around the west coast of Scotland. ICES J Mar Sci. 1998;55:846-58

44. Beevers ND, Kilbride E, Atkinson RJA, Neil DM. Hematodinium infection seasonality in the Firth of Clyde (Scotland) Nephrops norvegicus population: a re-evaluation. Dis Aquat Org. 2012;100:95-104.

45. Parmenter KJ, Vigueira PA, Morlok CK, Micklewright JA, Smith KM, Paul KS, et al. Seasonal prevalence of Hematodinium sp. infections of blue crabs in three South Carolina (USA) rivers. Estuar Coast. 2013;36:174-91.
46. Messick GA. Hematodinium perezi infections in adult and juvenile blue crabs Callinectes sapidus from coastal bays of Maryland and Virginia, USA. Dis Aquat Org. 1994;19:77-82.

47. Messick GA, Shields JD. Epizootiology of the parasitic dinoflagellate Hematodinium sp. in the American blue crab Callinectes sapidus. Dis Aquat Org. 2000;43:139-52.

48. Bower SM, Meyer GR, Phillips A, Workman G, Clark D. New host and range extension of bitter crab syndrome in Chionoecetes spp. caused by Hematodinium sp. Bull Eur Assoc Fish Pathol. 2003;23:86-91.

49. Love D, Rice S, Moles D, Eaton W. Seasonal prevalence and intensity of bitter crab dinoflagellate infection and host mortality in Alaskan Tanner crabs Chionoeceles bairdi from Auke Bay, Alaska, USA. Dis Aquat Org. 1993; 15:1-7.

50. Hudson DA, Shields JD. Hematodinium australis n. sp., a parasitic dinoflagellate of the sand crab Portunus pelagicus from Moreton Bay, Australia. Dis Aquat Org. 1994;19:109-19.

51. Lycett KA, Chung JS, Pitula JS. The relationship of blue crab (Callinectes sapidus) size class and molt stage to disease acquisition and intensity of Hematodinium perezi infections. PLoS ONE. 2018;13:e0192237.

52. Shields JD. The impact of pathogens on exploited populations of decapod crustaceans. J Invertebr Pathol. 2012;110:211-24.

53. Small HJ. Advances in our understanding of the global diversity and distribution of Hematodinium spp.-significant pathogens of commercially exploited crustaceans. J Invertebr Pathol. 2012;110:234-46.

54. Hamilton KM, Morritt D, Shaw PW. Genetic diversity of the crustacean parasite Hematodinium (Alveolata, Syndinea). Eur J Protistol. 2010;46:17-28.

55. Johnson L, Coates CJ, Albalat A, Todd K, Neil D. Temperaturedependent morbidity of "nicked" edible crab, Cancer pagurus. Fish Res. 2016:175:127-31.

56. Lohan KM, Reece KS, Miller TL, Wheeler KN, Small HJ, Shields JD. The role of alternate hosts in the ecology and life history of Hematodinium sp., a parasitic dinoflagellate of the blue crab (Callinectes sapidus). J Parasitol. 2012;98:73-84

57. Gruebl T, Frischer M, Sheppard M, Neumann M, Maurer A, Lee R. Development of an 185 rRNA gene targeted PCR based diagnostic for the blue crab parasite Hematodinium sp. Dis Aquat Org. 2002;49:61-70.

58. Small HJ, Neil DM, Taylor AC, Atkinson RJ, Coombs GH. Molecular detection of Hematodinium spp. in Norway lobster Nephrops norvegicus and other crustaceans. Dis Aquat Org. 2006;69:185-95.

59. Eigemann F, Burmeister A, Skovgaard A. Hematodinium sp. (Alveolata, Syndinea) detected in marine decapod crustaceans from waters of Denmark and Greenland. Dis Aquat Org. 2010;92:59-68.

\section{Publisher's Note}

Springer Nature remains neutral with regard to jurisdictional claims in published maps and institutional affiliations.

Ready to submit your research? Choose BMC and benefit from

- fast, convenient online submission

- thorough peer review by experienced researchers in your field

- rapid publication on acceptance

- support for research data, including large and complex data types

- gold Open Access which fosters wider collaboration and increased citations

- maximum visibility for your research: over $100 \mathrm{M}$ website views per year

At BMC, research is always in progress.

Learn more biomedcentral.com/submissions 